\title{
Development of Soil Distribution and Liquefaction Potential Maps for Downtown Area in Yangon, Myanmar
}

\author{
Zar Lee Tint ${ }^{\mathrm{a}}$, Nyan Myint Kyaw ${ }^{\mathrm{b}}$, Kyaw Kyaw ${ }^{\mathrm{a}, \mathrm{b}^{*}}$ \\ ${ }^{a}$ Department of Civil Engineering, Yangon Technological University, Yangon and 11181, Myanmar. \\ ${ }^{b}$ Department of Civil Engineering, Yangon Technological University, Yangon and 11181, Myanmar.
}

Received 11 February 2018; Accepted 25 March 2018

\begin{abstract}
The problem of soil against liquefaction during earthquakes is devastating geotechnical phenomenon. Soil against liquefaction is generally occurred in loose cohesionless saturated soil when pore water pressure increases suddenly due to earthquakes and shear strength of the soil decreases to zero. Yangon area has been chosen as the study area because it is the most populated and largest city in Myanmar and located in low to medium seismicity region. In this purpose, the liquefaction potential map have been prepared for site planners and decision makers to prevent loss of lives. Geographic Information System (GIS) is very useful in decision making about the area subjected to liquefaction. ArcGIS software is used to develop the liquefaction potential maps of the selected area in Yangon City. To perform in this study, the field borehole data for groundwater table, Standard penetration test (SPT), blow counts, dry density, wet density and fine content, etc. have been collected from the downtown area of this city. Firstly, the safety factor of soil liquefaction is computed by using NCEER (National Center of Earthquake Engineering Research, 1997) Method based on cyclic resistance ratio and cyclic stress ratio and then liquefaction Potential Index (LPI) values are determined using Luna and Frost Method, 1998. Finally, liquefaction potential maps are developed corresponding to the ground motions for annual probability of exceedance equal to $1 \%, 2 \%$ and $10 \%$ in 50 years.
\end{abstract}

Keywords: Liquefaction Potential Index; Geographic Information System (GIS); Yangon City; Liquefaction Potential Map; Earthquake; SPT Data.

\section{Introduction}

In the past decades, a huge amount of subsurface information has been incorporated in urban and rural area in many countries for various purposes such as disaster mitigation, infrastructure development and construction of high rise building. In the urban area, the underground condition below the Earth's surface operates the cost and feasibility of the construction projects from the aspects of physical properties of the foundation soil, depth of groundwater, and susceptibility of subsoil to liquefaction etc. Geotechnical database plays a significant role to investigate regional subsoil condition [4]. Sub-surface information is presented in various forms such as borehole logs, soil cross sections, soil test data sheets, geotechnical investigation reports, topographic maps, geological maps, and underground structure details. Seismic soil liquefaction continues to be a challenging problem, and attracts considerable attention from researchers all around the world. Liquefaction is one of the main effects of an earthquake that is responsibility to structural failure and damage to roads, pipelines and infrastructures [2]. It is one of the most serious geotechnical problems of public concern. For the study of subsurface geology, the generation of a geological database is important which can be done by the collection of borehole data.

\section{* Corresponding author: zarleetint@gmail.com \\ http://dx.doi.org/10.28991/cej-0309108}

$>$ This is an open access article under the CC-BY license (https://creativecommons.org/licenses/by/4.0/).

(C) Authors retain all copyrights. 
The liquefaction potential mapping is represented the process of identifying the changes in liquefaction hazard potential across an area and the process of evaluation both the response of soil layer due to the earthquake and the effect of variation in earthquake properties on the ground surface. The map of liquefaction potential identifies the areas with significant probabilities of severe disaster and ground disturbance during a seismic event. This map presents basic information concerning ground properties to assist in the design of the structure. Liquefaction potential map is very important for developing seismic risk analysis and mitigation strategy in densely populated urban area. Liquefaction potential map is a useful tool for determining the areas where specific investigations for liquefaction hazards are needed to project development.

The majority of liquefaction studies have concentrated on relatively clean sands. The soil liquefaction has been explored on soils within the grain size range of very silty sand to silt with or without some clay content. These silty soils are frequently encountered in engineering practice, and there is an abundance of evidence to show that they can be susceptible to liquefaction. As designers of earthquake resistant infrastructure, often in silty soil environments, engineers need to know which silty soils are susceptible to liquefaction. Soil liquefaction due to earthquakes may increase in damage to buildings, bridge and other infrastructures etc. Moreover, earthquakes induced liquefaction phenomena have been happened in many parts of the world. Then, many researchers have modified, improved, calibrated and validated the methods of liquefaction susceptibility analysis and mapping.

Yangon City is located closely to the seismically active zone. The downtown parts of the City are covered by the valley-filled deposit and Younger Alluvium soil. Most of the soil in Yangon is clay and silty soil. It is needed to investigate soil against liquefaction. In the study, the safety factor of soil against liquefaction is calculated by using NCEER method based on SPT data because it is used to predict the occurrence of liquefaction at each location as well as the resulting liquefied thickness. Field standard penetration test (SPT) data from about 67 numbers of boreholes in the Yangon selected area with different earthquake moment magnitudes $\left(M_{w}\right)$ is used for the evaluation of liquefaction potential. Soil layers with FS greater than 1.0 and FS less than or equal 1.0 are defined as non-liquefiable and liquefiable layers. Despite showing the liquefaction potential of a soil layer at a particular depth in the subsurface, FS does not show the degree of liquefaction severity at a liquefaction-prone site. Liquefaction potential index (LPI) values corresponding to the magnitude of the peak horizontal ground acceleration proposed by Luna and Frost Method (1998) provide an integration of liquefaction potential over the depth of soil profile and predict the performance of the whole soil column as opposed to a single soil layer at particular depth. Luna and Frost categorized the sites with LPI $=0$ as not likely to liquefy and categorized the sites with $0<$ LPI $\leq 5,5<$ LPI $\leq 15$ and LPI $>15$ as having minor, moderate and major liquefaction susceptibility, respectively. Liquefaction potential map based on LPI values are prepared with different earthquake for $1 \%, 2 \%$ and $10 \%$ probabilities of exceedance in 50 years in Yangon selected area.

The objective of liquefaction potential map is to evaluate liquefaction potentials at unsampled locations where borehole data are not available based on the measured liquefaction potentials at selected borehole locations. Soil distribution map is an important issue for calculation of soil liquefaction. In the study, an attempt has been made to prepare soil distribution and liquefaction potential map with the help of the available borehole data in Yangon, Myanmar.

\subsection{Background Problem}

Geographically, a larger part of Myanmar lies in the southern part of the Himalaya and the eastern margin of the Indian Ocean, hence exposed to bigger earthquakes. As Myanmar is an earthquake prone country, it has two important tectonic features and earthquake sources, one within Myanmar and the other in her neighborhood to the West. As the earthquake sources, the major active faults which have been seismically very hazardous for Myanmar are Sagaing fault, Kyaukkyan fault, Nan Pon fault, Kabaw fault, Myauk-U fault, Dawei fault, Gwegyo Thrust, and some major thrusts in north-west Myanmar. In recent times, Myanmar has experienced large magnitude earthquakes, related hazards and frequent landslide phenomena.

Building collapse is a major hazard. The severe damages of the large magnitude earthquakes might affect mostly on the rural house since they are not designed by structural engineers, even in the city where the old buildings existed. The population density tremendously increases in major cities; unfortunately, these large cities lie near or quite close to the major active faults in Myanmar (for an instance, the cities of Yangon, Bago, Taungoo, Napyitaw, Pyinmana, Kyaukse, Mandalay, and Myitkyina stand along the Sagaing Fault and Taunggyi City is near the Kyaukkyan Fault). In 17 December 1927, Yangon was hit a six-grade. The Bago (Pegu) earthquake (7.3 RS) of 5 May 1930, which caused widespread destruction of the town, is considered as a devastating disaster by Chhibber (1934). It killed approximately 500 people in Bago and 50 in Yangon that is situated at some 30 miles southwest of the epicenter - 30 miles south of Bago. The last record of the earthquake in Yangon had been struck $M=5.7,1978$. The other significant earthquakes in Yangon had been occurred in September 10, 1927 and December 17, 1927. These events also resulted in a certain amount of damage in Yangon. Some of the building in Yangon has the problems of the deformation of the foundation into the soil. The problem is the cause of soil liquefaction or cyclic softening. The historical and seismic records show that in addition to some major historical earthquakes in the distant past, there had been at least 17 large earthquakes with $M=7.0$ within the territory of Myanmar in the past 170 years. The recorded strong earthquakes in Myanmar are shown in Figure 1. 


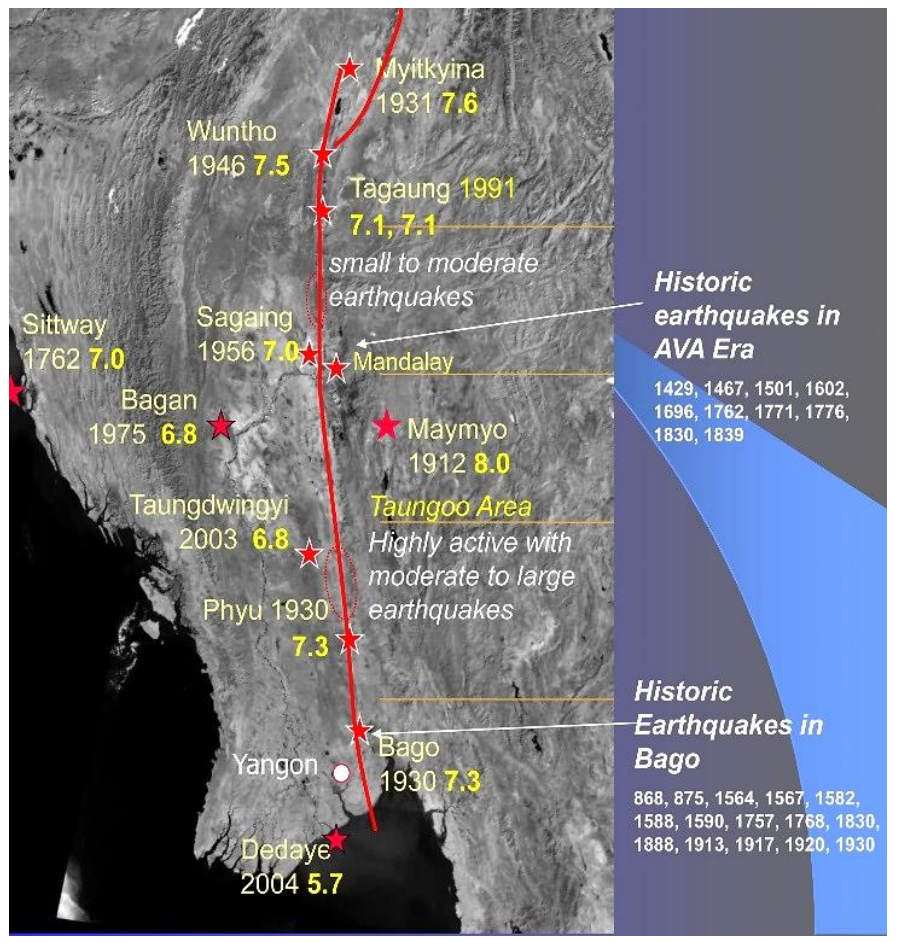

Figure 1. Significant of earthquake in Myanmar

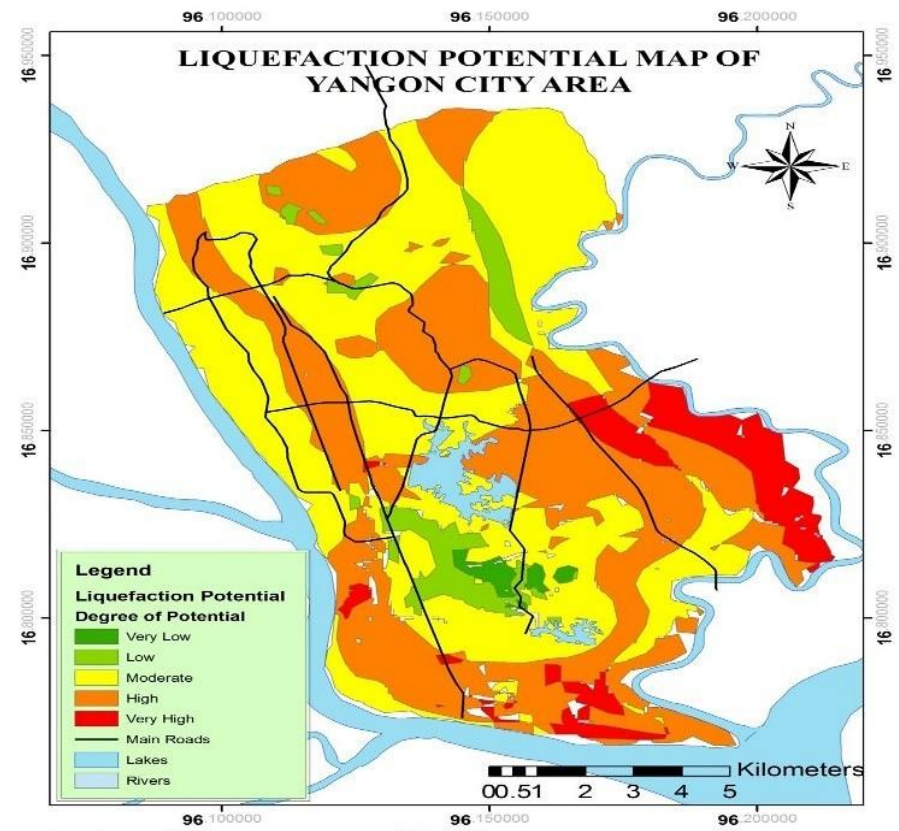

Figure 2. Liquefaction potential map of Yangon City area

In Yangon area at depth 6 meter, the liquefaction potential map associated with moment magnitude $\left(M_{w}=7\right)$ and peak ground acceleration $(\mathrm{a}=0.2 \mathrm{~g}$ ) was proposed by Htun, 2014 as shown in Figure 2. From this map, it is found that the thirty-six boreholes were considered and liquefaction hazards were categorized base on LPI values. i.e. none for LPI $=0$, low for $0<\mathrm{LPI} \leq 2$, moderate for $2<\mathrm{LPI} \leq 5$, high for $5<\mathrm{LPI} \leq 15$ and very high $\mathrm{LPI}>15$ determined by Sonmez Method, 2003. The liquefaction map was only suitable for shallow foundation in Yangon City area. To be upgraded the liquefaction Potential map for downtown area in Yangon, Myanmar, development of liquefaction potential and soil distribution maps are presented in the study.

\subsection{Geology and Geomorphology}

Yangon is a financial and populated city in Myanmar. It is located between Latitude $16.8861^{\circ} \mathrm{N}$ and Longitude $96.1951^{\circ} \mathrm{E}$ and $34 \mathrm{~km}$ from the sea in the coastal area. The Alluvial deposits (Pleistocene to Recent), the non-marine fluviatile sediments of Irrawaddy formation (Pliocene) and hard, massive sandstone of Pegu series (early-late Miocene) are mostly covered the Yangon area. Alluvial deposits are composed of gravel, clay, silts, sands and laterite which lie 
upon the eroded surface of the Irrawaddy formation at 3-4.6 m above mean sea level (MSL) [10]. The soft rock in Yangon comprise of sandstone, shale, limestone and conglomerate. Yangon covers an area of $598.8 \mathrm{~km} 2 \mathrm{having}$ a population of around six million people. Many buildings in ancient parts of the city are non-engineered structures. Most of the buildings are tall buildings in downtown area, Yangon. There are six townships in downtown parts of Yangon City in this study. The geological map of the Yangon city is shown in Figure 3.

Yangon region is tectonically bounded by the Indian-Burma Plates subduction in the west, Sagaing fault in the east, West Bago Yoma fault in the north, Kyaukkyan fault in the north-east, and the Andaman rift zone in the south. Yangon stands along the Sagaing Fault. The Bago earthquake, (7.3 RS) of 5 May 1930, is killed approximately 500 people in Bago and 50 in Yangon. Many earthquakes in and around Yangon City are shallow earthquakes related with Sagaing fault and Taikkyi fault [10].

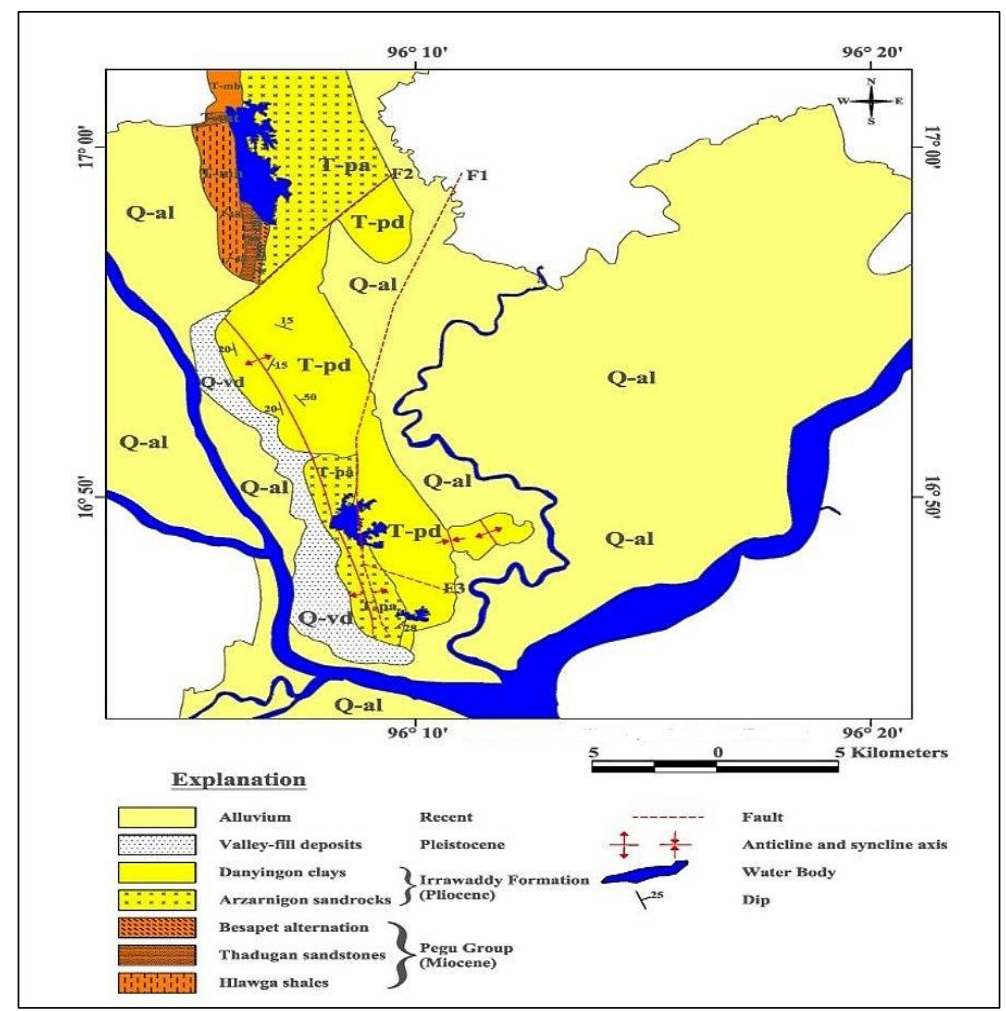

Figure 3. Geological map of the greater Yangon

\section{Assessment of Liquefaction Potential Index}

The liquefaction susceptibility analysis and mapping have further been modified, improved, calibrated and validated by many researchers such as Kang et al., 2014; Palacios et al., 2014 and others [5-9]. However, the Liquefaction Potential Index (LPI) was used to represent the damage potential at each site and then a comparison of the CPT-based strength profiles obtained before each of the major aftershocks was performed (J.J. Lees, 2015)[18]. It can be observed from the LPI contour maps that a high degree of liquefaction damages is likely to occur at a particular location for higher magnitude of earthquake and peak ground acceleration (Debojit Sarker, 2015) [19]. An overview of deterministic and probabilistic methods for the evaluation of liquefaction potential was made in Shpresa Gashi, 2015 [20].

The Liquefaction potential index (LPI) assesses the severity of liquefaction and calculates the manifestations of liquefaction, liquefaction damage or failure potential of liquefaction-prone area (Luna and Frost, 1998). LPI is evaluated by taking integration of one minus the liquefaction factors of safety along the entire depth of soil profiles limited to the depths ranging from 0 to $20 \mathrm{~m}$ below the ground surface at a specific location. The level of liquefaction severity with regard to LPI as per Iwasaki et al. (1982) and Luna and Frost (1998) is shown in Table 1. The safety factor against liquefaction (FS) and the corresponding liquefaction potential index (LPI) are established by comparing the seismic demand expressed in terms of cyclic stress ratio (CSR) to the capacity of liquefaction resistance of the soil expressed in terms of cyclic resistance ratio (CRR).

\subsection{Method based on the Standard Penetration Test}

The most comprehensive liquefaction data catalogs are based on Standard Penetration Test (SPT) blow counts. The measured SPT blowcount $\left(N_{S T P}\right)$ is first normalized for the overburden stress at the depth of the test and corrected to a standardized value of $\left(N_{1}\right)_{60}$. Using the recommended correction factors given by Robertson and Fear (1996), the corrected SPT blowcount is calculated with [12]: 


$$
\left(N_{1}\right)_{60}=N_{S P T} C_{N} C_{E} C_{B} C_{R} C_{S}
$$

Where, $C_{E}$ is corrected energy ratio $\left(E_{R}\right) . C_{B}$ is the correction factor of borehole diameter, $C_{R}$ is correction factor for rod length and $C_{S}$ is the correction for sampler with or without liner. The correction factor $\left(C_{N}\right)$ normalizes the measured blowcount to an equivalent value under one atmosphere of effective overburden stress:

$\mathrm{C}_{N}=\sqrt{\frac{p_{a}}{\sigma^{\prime}{ }^{\prime}}}$

Where $\sigma^{\prime}{ }_{v 0}$ is the vertical effective stress at the depth of $N_{S T P}$ and $P_{a}$ is one atmosphere of pressure.

The clean-sand equivalent is made based on the fines content of the soil sample:

clean - sand equivalent $\left(N_{1}\right)_{60}=\left(N_{1}\right)_{60}+\Delta\left(N_{1}\right)_{60}$

The correction factor is computed with the linear function:

For $\mathrm{FC} \leq 5 \%$

For $5 \%<\mathrm{FC}<35 \%$

For $\mathrm{FC} \geq 35 \%$

$$
\begin{aligned}
& \Delta\left(\mathrm{N}_{1}\right)_{60}=0.0 \\
& \Delta\left(N_{1}\right)_{60}=7 \times(F C-5) / 30 \\
& \Delta\left(N_{1}\right)_{60}=7.00
\end{aligned}
$$

Where FC is the fines content (percent finer than $0.075 \mathrm{~mm}$ )

\subsection{Cyclic Resistance Ratio}

As a rule of thumb, any soil that has an SPT value higher than 30 will not liquefy. As mentioned earlier, resistance to liquefaction of a soil depends on its strength measured by SPT value. Researchers have found that resistance to liquefaction of a soil depends on the content of fines as well. The following equation can be used for clean sand [1-6].

$$
100 \times C R R_{M=7.5}=\frac{95}{34-\left(N_{1}\right)_{60}}+\frac{\left(N_{1}\right)_{60}}{1.3}-\frac{1}{2}
$$

Where $C R R_{M=7.5}$ is the cyclic resistance ratio for an $M_{w}=7.5$ earthquake and $\left(N_{1}\right)_{60}$ is the corrected, clean-sand equivalent SPT value. A value of $\left(N_{1}\right)_{60}>30$ indicates an unliquefied soil with an infinite CRR.

\subsection{Cyclic Stress Ratio}

The representative horizontal shear stress is computed with a simplified equation suggested by Seed and Idriss (1971) and expressed in terms of the cyclic stress ratio (CSR) given by Seed et al.( 1985):

$$
\mathrm{CSR}=0.65 \frac{a_{\max }}{g} \frac{\sigma_{v 0}}{\sigma_{v 0}^{\prime}} r_{d}
$$

Where $\mathrm{g}$ is the acceleration due to gravity $(9.81 \mathrm{~m} / \mathrm{s} 2), \sigma_{v 0}$ is the total vertical overburden stress, and ${\sigma^{\prime}}_{v 0}$ is the effective vertical overburden stress at the depth of interest. The stress reduction coefficient parameter accounts for the flexibility of the soil profile, $r_{d}[7,22]$;

$\mathrm{r}_{d}=1.0+1.6 * 10^{-6}\left(z^{4}-42 z^{3}+105 z^{2}-4200 z\right)$

$\mathrm{z}$ is the depth below the ground surface in meters.

$M_{w}$ can be used to measure the whole spectrum of ground motions. Moment magnitude is defined as a function of the seismic moment $M_{0}$. This measures the extent of deformation at the earthquake source and can be evaluated as follows [3, 24]:

$$
\mathrm{M}_{0}=G A \Delta \mu
$$

Where $\mathrm{G}$ is the shear modulus of the material surrounding the fault, $\mathrm{A}$ is the fault rupture area and $\Delta \mathrm{u}$ is the average slip between opposite sides of the fault. $M_{w}$ is thus given by:

$$
\mathrm{M}_{\mathrm{w}}=0.67 \log \mathrm{M}_{0-} 10.7
$$

Where, $M_{0}$ is expressed in ergs.

Moment magnitude is expected from the Sagaing Fault located near Yangon City. Cornell, et al. (1979) proposed the mean of $\log$ peak ground acceleration (in units of $\mathrm{g}$ ) and peak ground acceleration is calculated with the source distance. 


$$
\ln (P G A)=-0.152+0.859 \mathrm{M}_{w}-1.803 \ln (R+25)
$$

Where, PGA $=$ Peak ground acceleration

$$
\begin{aligned}
\mathrm{Mw} & =\text { Moment magnitude } \\
\mathrm{R} & =\text { Source Distance }
\end{aligned}
$$

\subsection{Factors Affection the liquefaction Susceptibility}

Clays remain non susceptible to liquefaction, although sensitive clays exhibit deformation-softening behavior similar to that of liquefied soil (Kramer 1996). Fine-grained soils that satisfy each of the four Chinese criteria (Wang, 1979) may be considered susceptible to significant strength loss [11-14]:

- Fraction finer than $0.005 \mathrm{~mm} \leqslant 15 \%$

- Liquid Limit $(\mathrm{LL}) \leqslant 35 \%$

- Natural water content $\geqslant 0.9 \mathrm{LL}$

- Liquid Index $\leqslant 0.75$

When clay is contained in the sand and the cohesion is high, liquefaction does not occur, and if it does, the displacement is small.

Liquefaction susceptibility decreases strongly with increasing depth to the water table (Obermeier, 1995). Normally liquefaction is not expected at a place where water table is greater than $10 \mathrm{~m}$. Depth to groundwater table is an important issue in the liquefaction evaluation because it is controlled effective normal stress exerted on soil. The cohesionless soil in a loose relative density state is susceptible to liquefaction. Uniformly graded nonplastic soil tends to form more unstable particle arrangements and is more susceptible to liquefaction than well-graded soil. Human-made deposits (Fill) those places without compaction are also very likely to be susceptible to liquefaction (Kramer, 1986) [23]. Although building loads are not considered in the liquefaction analysis, the building loads must be included in all liquefactioninduced settlement, bearing capacity, and stability analyses [25].

\section{Determination of liquefaction Potential Index}

If the computed cyclic resistance ratio (CRR) of the soil is less than or equal to cyclic stress ratio (CSR) generated by the earthquake, liquefaction is assumed to occur at that location. The factor of safety against liquefaction $\left(F S_{L i q}\right)$ is defined with (Ishihara, 1993) [15-17];

$\mathrm{FS}=\frac{\mathrm{CRR}}{\mathrm{CSR}}$

That is the soil at the depth of the measured SPT blowcount is predicted to liquefy if FS $\leq 1.0$, while FS $>1.0$ indicates no liquefaction. When the clean-sand equivalent $\left(N_{1}\right)_{60}$ is greater than 30 , the soil is considered to be unliquefiable.

To Liquefaction Potential Index (LPI) is a single-valued parameter to evaluated regional liquefaction potential. LPI at a site is computed by integrating the factor of safety $\left(F S_{\text {Liq }}\right)$ along the soil column. A weighting function is added to give more weight to the layers closer to the ground surface [1].

For the soil profiles, the Liquefaction Potential Index (LPI) proposed by Luna 1995, Luna and Frost 1998 can be expressed as follows [1]:

$$
\begin{aligned}
\mathrm{LPI} & =\sum \mathrm{F}_{i}(z) \mathrm{W}_{\mathrm{i}} \mathrm{H}_{\mathrm{i}} \\
F_{i} & =1-\mathrm{FS} \text { for } \mathrm{FS}<1.0 \\
F_{i} & =0 \text { for } \mathrm{FS} \geq 1 . \\
W_{i} & =10-0.5 \mathrm{z} \text { for } \mathrm{z} \leq 20 \mathrm{~m} \\
W_{i} & =0 \text { for } \mathrm{z}>20 \mathrm{~m}
\end{aligned}
$$

Where $\mathrm{n}$ denotes the number of discretized layers, Hi is the thickness of the discretized layer, and $F_{i}$ denotes the liquefaction severity for layer which is a function of the FS defined in Equation. Finally, $W_{i}$ is the weighting function as defined in Equation.

The categories of liquefaction severity were modified by Luna and Frost (1998) as shown in Table 1. Also, the category adopted in this study is proposed, as discussed below [7]. 
Table 1. Historic liquefaction severity assessed from the liquefaction potential index (LPI)

\begin{tabular}{ccc}
\hline LPI & Iwasaki et al. (1982) & Luna and Frost (1998) \\
\hline 0 & Not likely & Little to none \\
$0<\mathrm{LPI} \leq 5$ & Minor & Minor \\
$5<\mathrm{LPI} \leq 15$ & - & Moderate \\
$15<$ LPI & Severe & Major \\
\hline
\end{tabular}

The liquefaction potential index (LPI) quantifies the severity of liquefaction and predicts surface manifestations of liquefaction, liquefaction damage or failure potential of a liquefaction-prone area. LPI is computed by taking integration of one minus the liquefaction factors of safety along the entire depth of soil column limited to the depths ranging from 0 to $20 \mathrm{~m}$ below the ground surface at a specific location.

Data Acquisition is one of the most difficult parts of the research work. It is time consuming and more personal relations are required, in order to contact people in institutions that might have relevant data. Many borehole data 67 bore logs were collected for the liquefaction analysis. The borehole records contain the geotechnical information such as grain size distribution, Atterberg limits, N-values, moisture content, density and unit weight.

The factor safety of soil for earthquakes with different magnitude is computed by using Equation 4. Factor of safety (FS) at different depth of soil profiles is evaluated using different moment magnitudes 7.5, 7.93 and 8.13 $\mathrm{M}_{\mathrm{w}}$ with peak ground acceleration $0.25 \mathrm{~g}, 0.36 \mathrm{~g}$ and $0.43 \mathrm{~g}$. The locations of borehole data are shown in Figure 4.

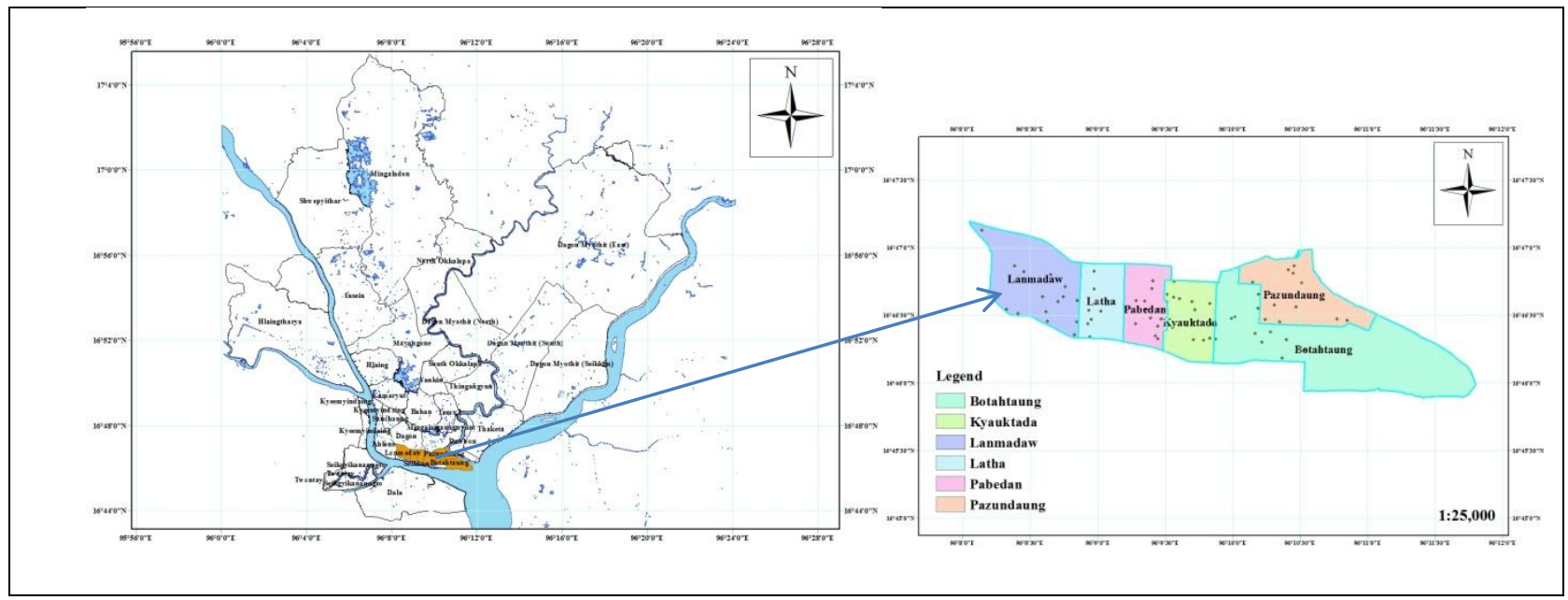

Figure 4. Location map of boreholes

\section{Determination of Soil Distribution Map}

Soil investigation plays an important role to know the sub-soil condition. Soil Report is used to classify soil condition under the ground by using the results of particle size distribution from the sieve analysis and hydrometer test. There are three basic types of soil: sand, silt and clay. But most soils are composed of a combination of the different types. Sand is fairly coarse and loose so water is able to drain through it easily. Silt can be thought of as fine sand, and it will hold water better than sand. Clay is very fine-grained soil. Soil Distribution Mapping is one of the most geotechnical engineering fields.

The study area has been considered at six townships in Yangon because these townships are located near the river. The 67 borehole data in this area are collected for soil classification. Soil distribution maps with different depth are proposed by using ArcGIS software in Yangon selected area. The identification of soil types is SM, CL, CH, MH, ML and SC by classifying Unified Soil Classification System.

Latha, Pabedan and Kyauktada Townships are the $\mathrm{CH}$ soil type up to $5 \mathrm{~m}$ depth. In Latha, Pabedan and Kyauktada Townships, it is found SM soil type up to $10 \mathrm{~m}$ depth. Most area in Latha, Lanmadaw, Pabedan and Kyauktada Townships are covered by SM soil type up to $15 \mathrm{~m}$ depth. SM soil type is covered in the downtown parts of Yangon City up to $20 \mathrm{~m}$ depth. 


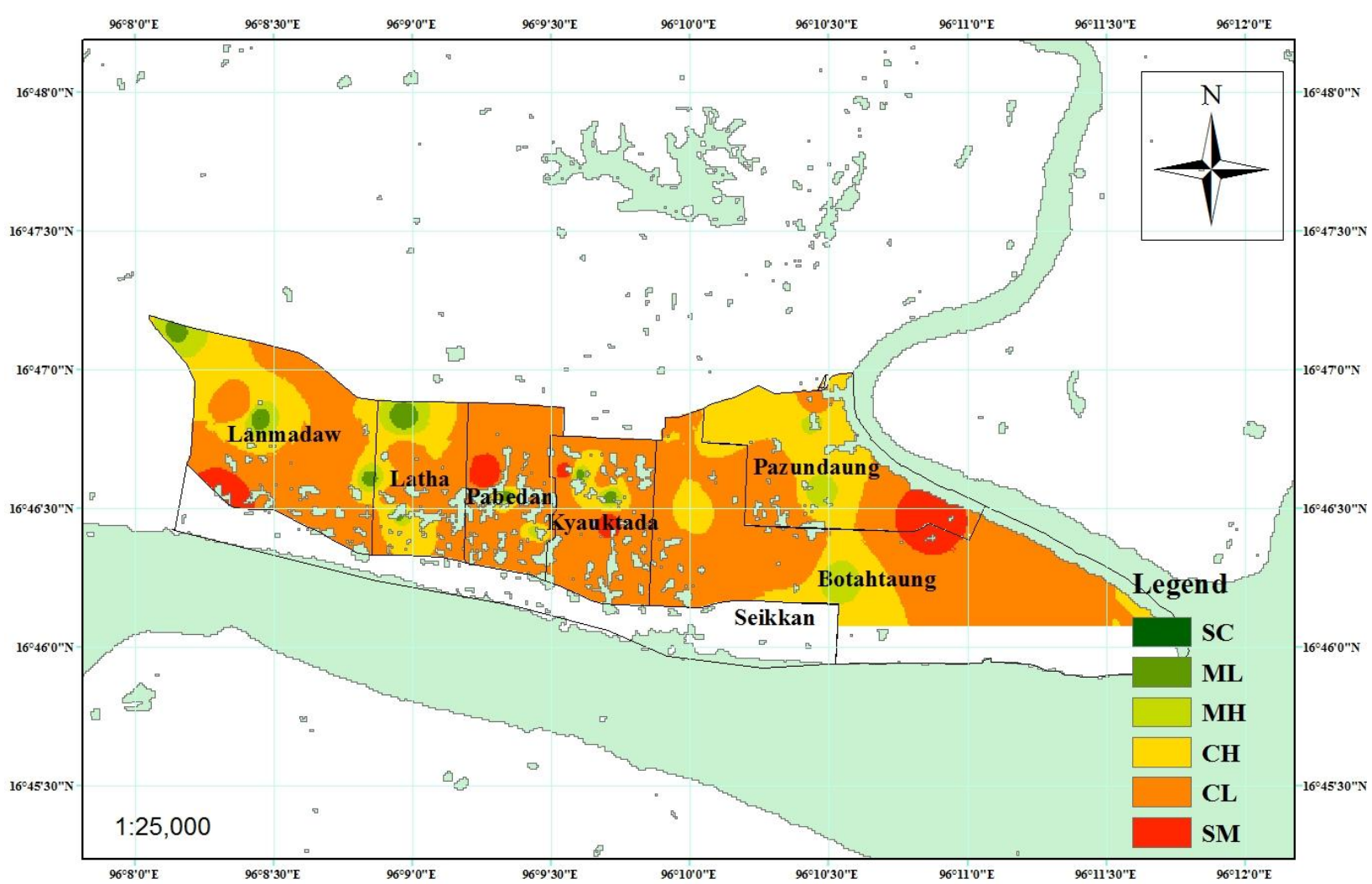

Figure 5. Soil distribution map at $5 \mathrm{~m}$ depth

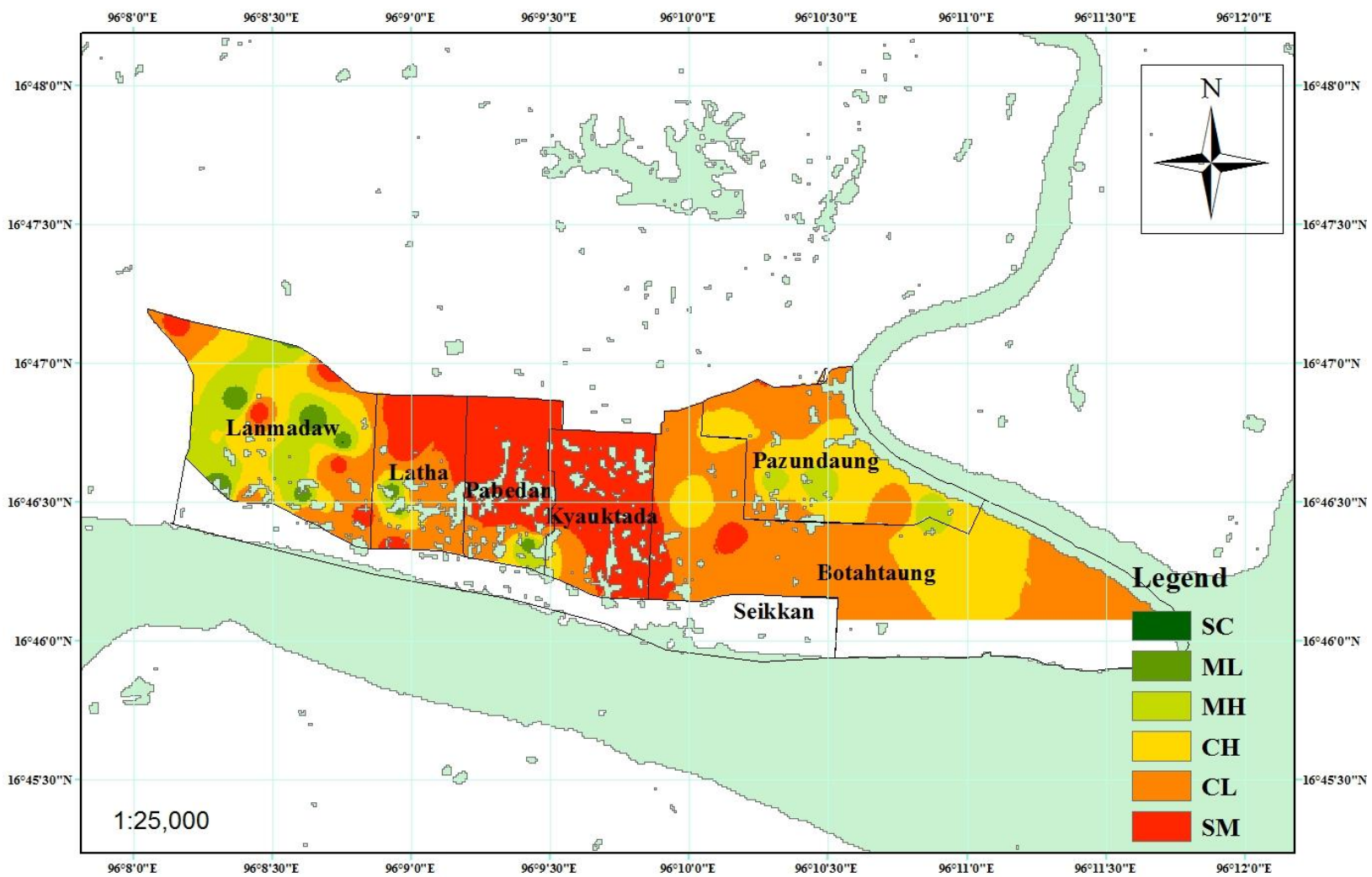

Figure 6. Soil distribution map at $10 \mathrm{~m}$ depth 


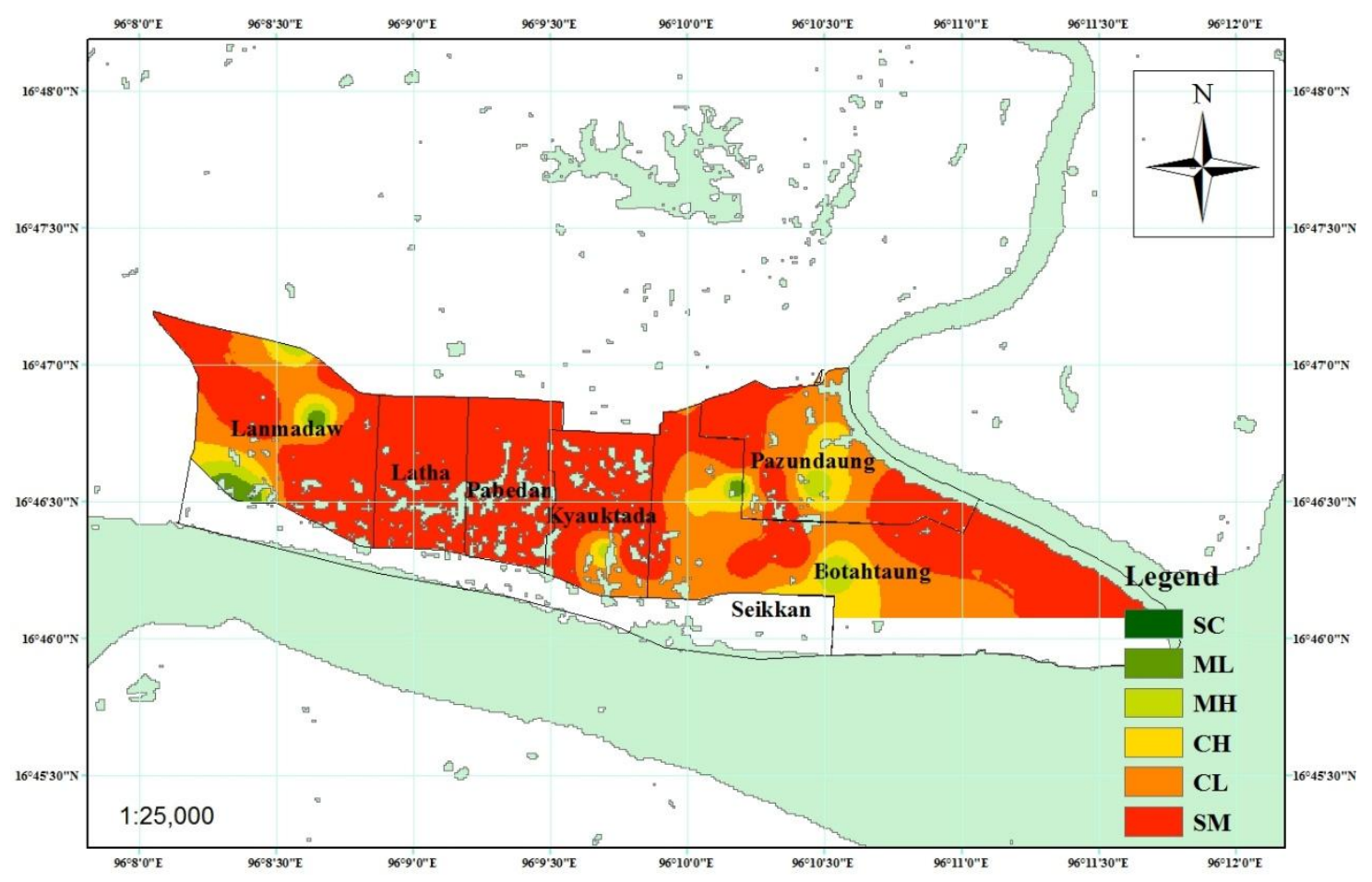

Figure 7. Soil distribution map at $15 \mathrm{~m}$ depth

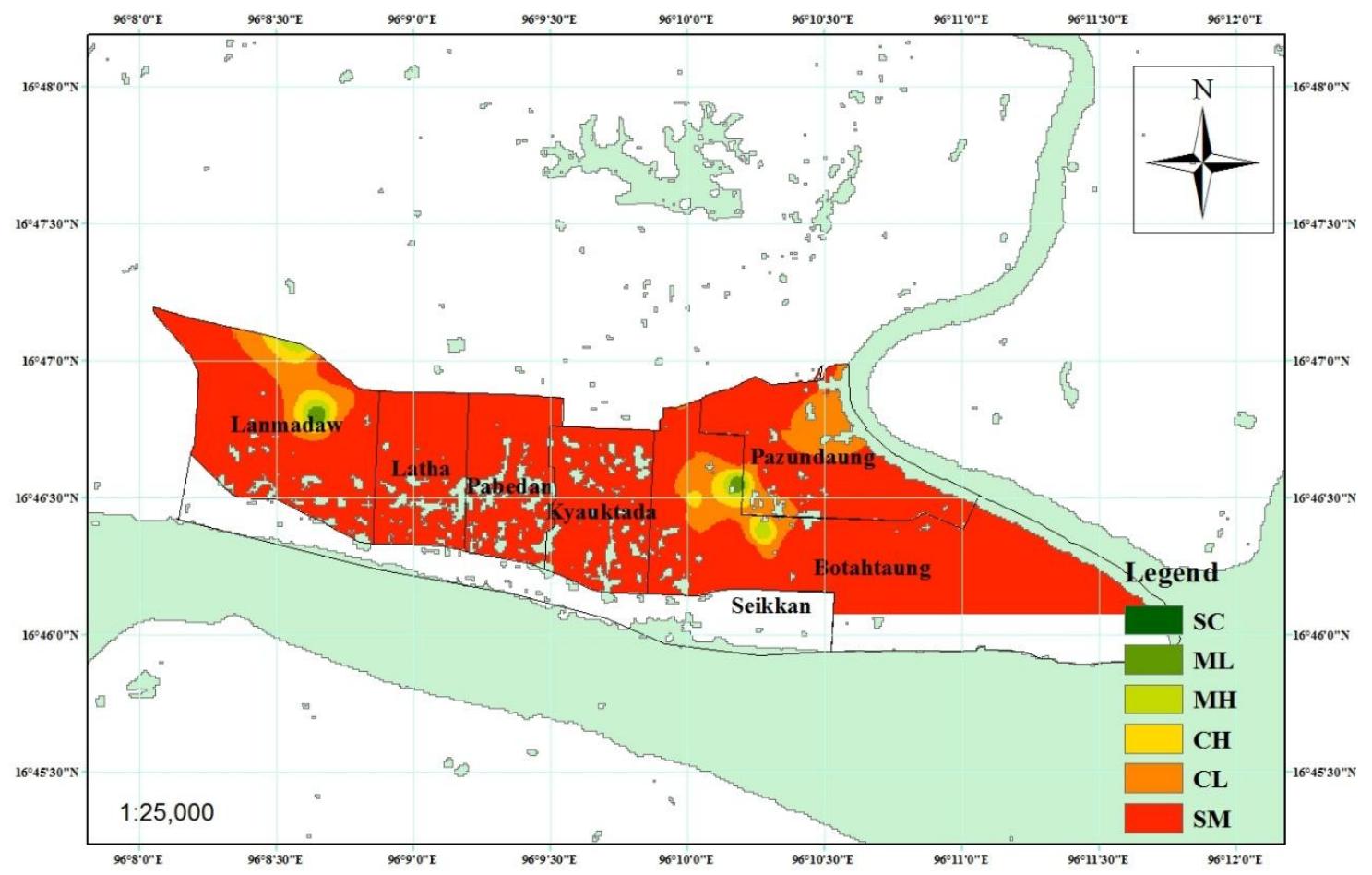

Figure 8. Soil distribution map at $20 \mathrm{~m}$ depth

\section{Development of Liquefaction Potential Map}

LPI values of sixty seven (67) borehole locations are evaluated by using NCEER method at a specific location of the city. Liquefaction hazards are categorized based on LPI values, i.e. little to none for LPI $=0$, minor for $0<\mathrm{LPI} \leqslant 5$, moderate for $5<$ LPI $\leqslant 15$ and major for $15<$ LPI according to the method proposed by Luna and Frost (1998). Liquefaction Potential Maps using ArcGIS software are shown in Figures 9, 10 and 11. The highest LPI values are found in the area located near the river. 
The Yangon City area is evaluated the liquefaction potential of soil. A total of 67 numbers of borehole data in this area, both undisturbed and disturbed soil test reports were collected from Yangon City Development Committee and professionals working in geotechnical engineering field. This study attempts to calculate factor safety against liquefaction (FS) and corresponding liquefaction potential indices (LPI) for the seismic scenario for the city using SPT based semiempirical producer.

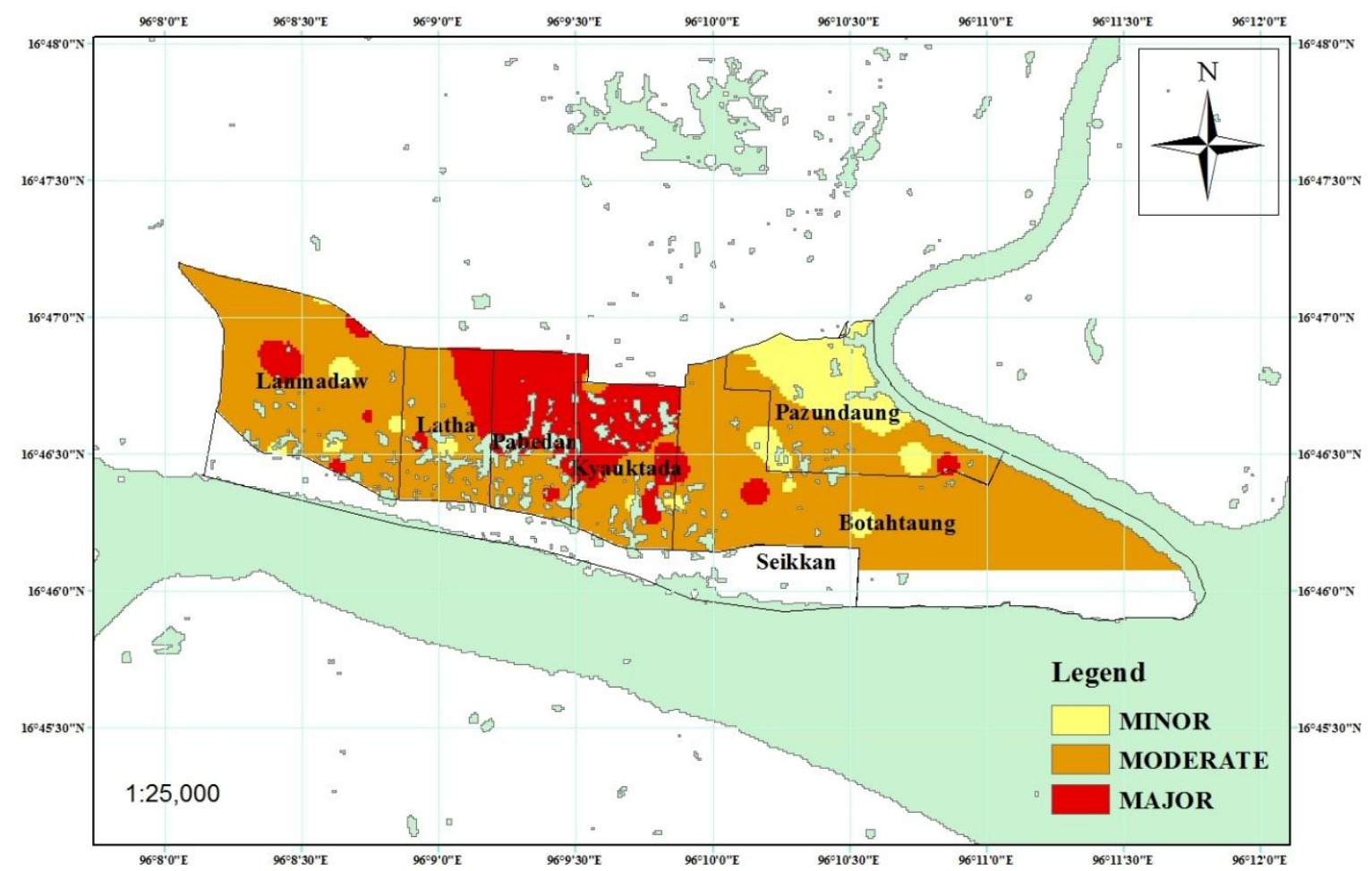

Figure 9. Liquefaction potential map of Downtown Area in Yangon for 1\% probability of exceedance in 50 years

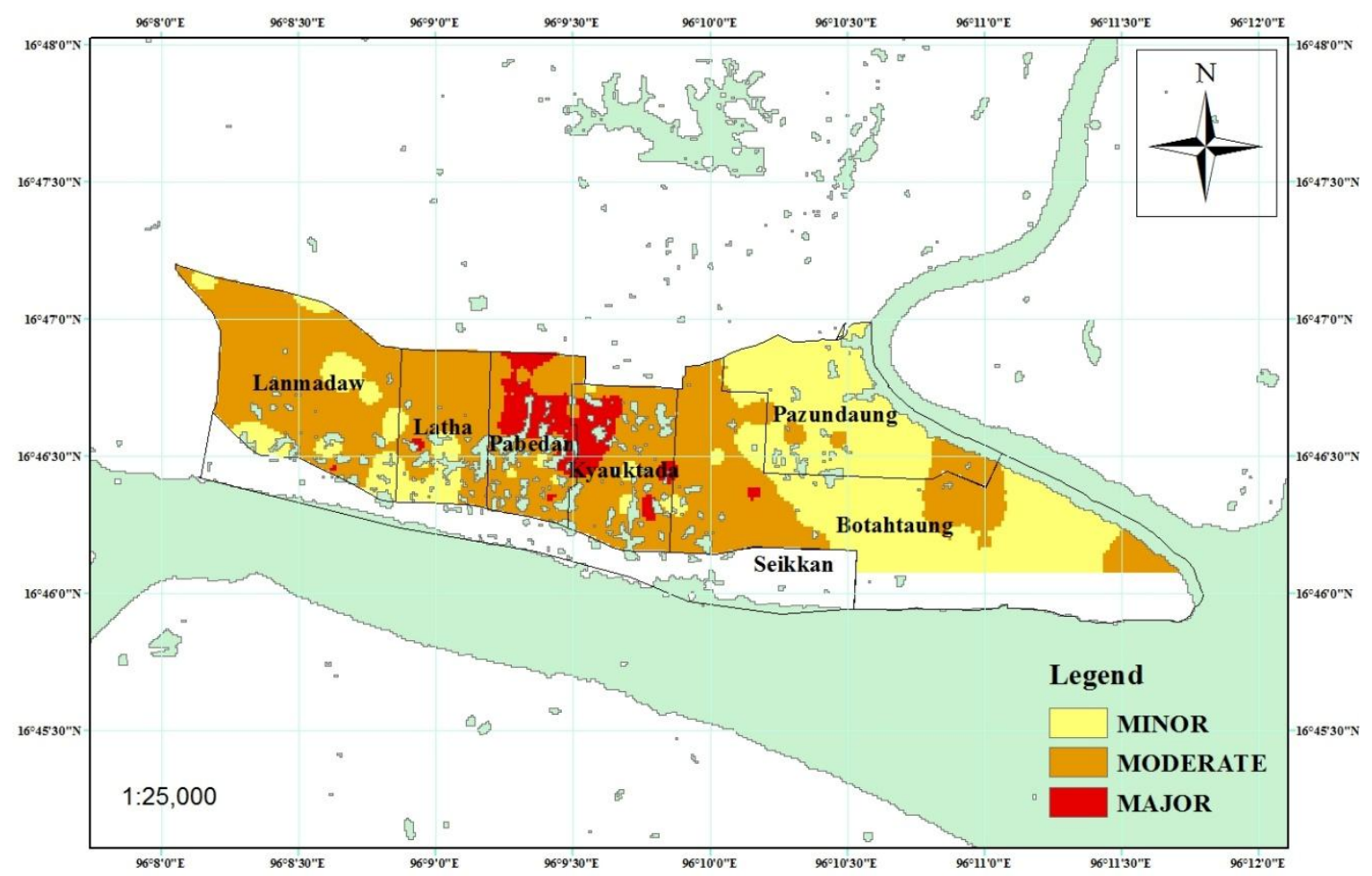

Figure 10. Liquefaction potential map of Downtown Area in Yangon for $2 \%$ probability of exceedance in 50 years 


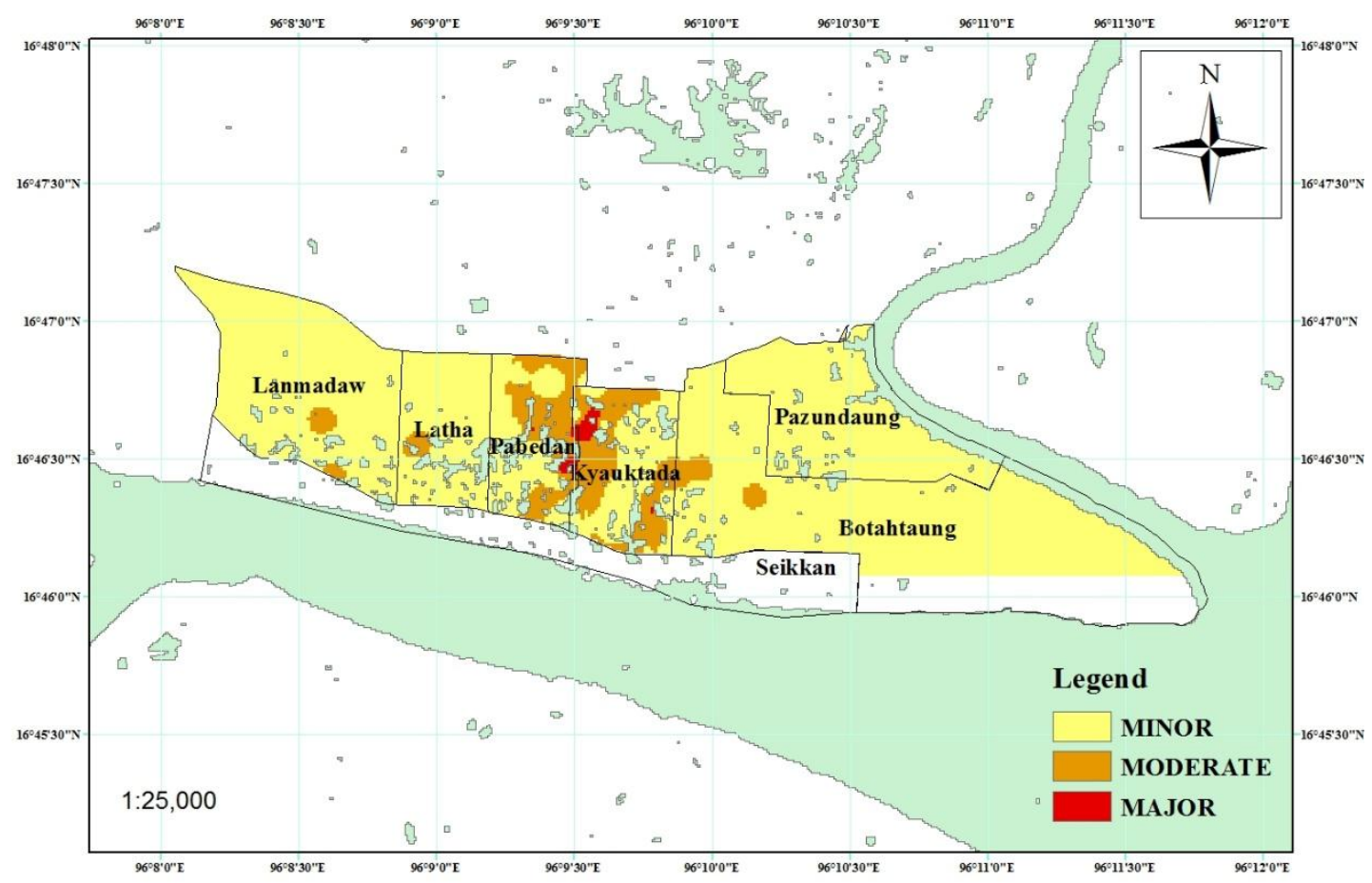

Figure 11. Liquefaction potential map of Downtown Area in Yangon for $10 \%$ probability of exceedance in 50 years

\section{Results and Discussions}

The development of soil liquefaction susceptibility map of Yangon, Myanmar was presented in the sudy. Soil liquefaction has occurred in fine to medium sands and silty sand and sands containing low plasticity. The subsurface soil of Yangon area up to the depth of $20 \mathrm{~m}$ was formed of Pleistocene and Alluvium soil. Most of the soil in the area was silty sand as shown in Figure 8. Therefore, it was needed to develop the liquefaction potential maps for these areas.

The liquefaction potential map of Yangon selected area offered a quantitative approach for mapping liquefaction susceptibility. Seismic soil liquefaction potential in terms of LPI was proposed at 67 sites across the area of the Yangon City and the maps of LPI values were developed to demonstrate the spatial distribution of liquefaction potential. These LPI maps could provide an indication of geographic variability of liquefaction effects and different kinds of probable surface manifestations of liquefaction. Spatial distribution of liquefaction potential map for earthquakes of $1 \%, 2 \%$, and $10 \%$ probability of exceedance in 50 years was quantity presented in form of maps showing the liquefaction potential index (LPI). The maps of LPI were proposed for the city to predict the occurrence of damaging liquefaction for the earthquake of magnitude $M_{w}=7.5, M_{w}=7.93$ and $M_{w}=8.13$ of $a_{\max } 0.25 \mathrm{~g}, 0.36 \mathrm{~g}$ and $0.43 \mathrm{~g}$ were shown in Figures 9,10 , and 11. These maps showed the liquefaction vulnerability at different sites of the city. The liquefaction susceptibility for sites with LPI $>15$ is very high and the liquefaction is very unlikely at sites with LPI $<5$.

The liquefaction potential map of Yangon selected area was developed for $1 \%$ probability of exceedance in 50 years with moment magnitude $M_{w}=8.13$ and peak ground acceleration, $a_{\max }=0.43 \mathrm{~g}$ shown in Figure 9 . The liquefaction potential map for $2 \%$ probability of exceedance in 50 years with $M_{w}=7.93$ and $a_{\max }=0.36 \mathrm{~g}$ was prepared in Figure 10. It was shown in Figure 11 that the liquefaction potential map was prepared with $5 \%$ probability of exceedance in 50 years $\left(M_{w}=7.5\right.$ and $\left.a_{\max }=0.25 \mathrm{~g}\right)$.

Most of the area namely, Pabedan and Kyauktada Township were major of liquefaction and other townships suffered the minor problem of liquefaction with $1 \%$ probability of exceedance in 50 years as shown Figure 9. LPI values of the area varied from 2.47 to 16.75 and the liquefaction potentials are categorized from minor to major in the figure. As can be seen in Figure 10, Pabedan, Kyauktada, Lanmadaw and Latha Twonships are moderate and major of liquefaction susceptibility and Botahtaund and Pazundaung Townships were lower than 5 for $2 \%$ probability of exceedance in 50 years. The LPI values ranged from 2.09 to 13.69 in the figure and so liquefaction susceptible are categorized from minor to moderate. Some area in Pabedan and Kyauktada Townships were moderate of liquefaction susceptibility and other townships were minor of liquefaction susceptibility for $10 \%$ probability of exceedance in 50 years shown in Figure 11. The LPI values varied from 0 to 4.57 and so liquefaction potentials are categorized from none to minor in the figure.

The results showed that the thickness of discrete soil layer was very important in liquefaction soil. Luna and Frost method is suitable for the evaluation of liquefaction soil with various depths of soil column because of including the 
thickness of discrete soil layer. It is difficult to collect deep borehole data of soil profile in Yangon City. So this method is good to use in Yangon data, Myanmar. The liquefaction potential maps in the study was used to be suitable for deep foundation in Yangon.

\section{Conclusion}

The liquefaction potential map indicated that the selected areas were higher to liquefaction susceptibility during strong earthquake such as $1 \%$ probability of exceedance in 50 years. Liquefaction potential was depended on the seismological aspects, such as ground motions levels and earthquake magnitude. Selection of appropriate peak horizontal ground acceleration (PGA) for the scenario earthquake can be an uncertainly for future application of the method. The liquefaction potential maps were generated for Yangon city to predict the occurrence of damaging liquefaction for $1 \%, 2 \%$ and $10 \%$ probability of exceedance in 50 years. The previous liquefaction potential map was useful for shallow foundation because it was considered $6 \mathrm{~m}$ depth of soil profile. The proposed liquefaction potential maps had been considered $1 \%, 2 \%$ and $10 \%$ probability of exceedance in 50 years and $20 \mathrm{~m}$ depth of soil profiles. Therefore, the liquefaction potential maps presented in the study would be benefited for the designers and site planners to check the vulnerability of the proposed work with respect to the liquefaction of soil at the particular area of Yangon City.

\section{Acknowledgements}

The author extends her thanks to the Yangon City Development Committee (YCDC), Committee for Quality Control of High-Rise Building Construction Projects (CQHP) in Myanmar and professional workers in the geotechnical engineering field for providing the borehole data at different sites in the study area. I would also like to thank Dr. Nyan Myint Kyaw and Dr. Kyaw Kyaw for their care and support.

\section{References}

[1] T.I. Mote J.N. Dismuke. "Liquefaction hazard maps for Australia.” World Conferences on Earthquake Engineering (2012). http://www.iitk.ac.in/nicee/wcee/article/WCEE2012_3982.pdf.

[2] H.S. Kim and C.K. Chung. "Real-time LPI-based Assessment of the Liquefaction Potential of the Incheon Port in Korea." World Conferences on Earthquake Engineering (2012). http://www.iitk.ac.in/nicee/wcee/article/WCEE2012_3356.pdf.

[3] T. L. Youd, Member, ASCE, and I. M. Idriss, Fellow. "Liquefaction Resistance of the Soils: Summary Report from the 1996 NCEER and 1998 NCEER/NSF Workshops on Evaluation of Liquefaction Resistance of Soils." Journal of Geotechnical and Geoenvironmental Engineering (ASCE, 2001): 297-311. http://dx.doi.org/10.1061/(ASCE)1090-0241(2001)127:10(817).

[4] J. Dixit, D. M. Dewaikar, and R. S. Jangid. “Assessment of Liquefaction Potential Index for Mumbai City.” Journal of Natural Hazards and Earth System Sciences (2012): 12-2759. https://www.nat-hazards-earth-syst-sci.net/12/2759/2012/nhess-12-27592012.pdf.

[5] Md. Zilllur Rahman, Sumi Siddiqua and A.S.M. Maksud Kamal. "Liquefaction Hazard Mapping by Liquefaction Potential Index for Dhaka City.” Enigneering Geology (2015). Bangladesh: 137-147. https://doi.org/10.1016/j.enggeo.2015.01.012.

[6] Alan F. Rauch "Empirical Method for Predicting Surface Displacements due to Liquefaction-Induced Lateral Spreading in Earthquake.” (1997): 111-120. http://hdl.handle.net/10919/30346.

[7] T.I. Mote J.N. Dismuke. "Liquefaction hazard maps for Australia". Paper of all World Conferences on Earthquake Engineering (2012). http://www.iitk.ac.in/nicee/wcee/article/WCEE2012_3982.pdf.

[8] Rama Mohan Pokhrel, Jiro Kuwana, Shinya Tachiban. “A Kriging Method of Interpolation Used to Map Liquefaction Potential over Alluvial Ground.” Journal of Engineering Geology (2013): 26-37. https://doi.org/10.1016/j.enggeo.2012.10.003.

[9] Sumedh Yamaji Mhaske and Deepankar Choudhury. "GIS-based Soil Liquefaction Susceptibility Map of Mumbai City for Earthquake Events.” Journal of Applied Geophysics (2010): 216-225. https://doi.org/10.1016/j.jappgeo.2010.01.001.

[10] Myo Thant. "Probabilistic Seismic Hazard Assessment for Yangon Region, Myanmar." Journal of ASEAN Engineering Part C (2012): 117. http://www.seed-net.org/wp-content/uploads/2015/12/PROBABILISTIC-SEISMIC-HAZARD-ASSESSMENT-FORYANGON-REGION-MYANMAR.pdf.

[11] Mamoru Mimura, Koji Yamamoto. "Development of Geoinformatic Database and its Utilization to Engineering Practice." Journal of Civil Engineering Research (2014): 1-13. http://doi.org/10.5923/c.jce.201402.01.

[12] Ming-Huei WANG, Ming-Hong CHEN and Chin-Hsiung LOH. "Liquefaction Potential Study of Taiwan." World Conferences on Earthquake Engineering (2000). http://www.iitk.ac.in/nicee/wcee/article/1310.pdf.

[13] Susumu IAI, Mamoru MIMURA, Masahiro CHIGIRA, Toshitaka KAMAI, Roy, C. SIDLE, Hiroshi SUWA, Takashi SAITO, and Tetsuo TOBITA. "Geo-disaster Prediction and Geo-hazard Mapping in Urban and Surrounding Areas Progress Report in FY 2006.” Annuals of Disas. Prev. Res (2006). http://www.dpri.kyoto-u.ac.jp/nenpo/no49/49c0/a49c0p03.pdf.

[14] Griffen L. Erickson, Steven F. Bartlett, Barry J. Solomon, Loren R. Anderson and Michael J. Olsen. "Probabilistic Liquefaction Potential Mapping of Salt Lake Valley, Utah.” http://civil.utah.edu/ bartlett/ULAG/Spectra-Erickson.pdf. 
[15] Jennifer A. Lenz, Laurie G. Baise. "Spatial Variability of Liquefaction Potential in Regional Mapping using CPT and SPT Data." Soil Dynamics and Earthquake Engineering 27 (2007): 690-702 https://doi.org/10.1016/j.soildyn.2006.11.005.

[16] Ross W. Boulanger and I. M. Idriss. "Probabilistic Standard Penetration Test-Based Liquefaction-Triggering Procedure." Journal of Geotechnical and Geoenvironmental Engineering (October 2012). http://dx.doi.org/10.1061/(ASCE)GT.19435606.0000700

[17] C. Hsein Juang and Tao Jiang. "Assessing Probability-Based Methods for Liquefaction Potential Evaluation." Journal of Geotechnical and Geoenvironmental Engineering (July 2002): 580-589. https://doi.org/10.1061/(ASCE)1090-0241(2002)128:7(580).

[18] J.J. Lees, R.H.Ballagh, R.P.Orense and S.vanBallegooy. "CPT-based Analysis of Liquefaction and Re-liquefaction following the Canterbury earthquake sequence.” Soil Dynamics and Earthquake Engineering (2015). http://dx.doi.org/10.1016/j.soildyn.

2015.02.

[19] Debojit Sarker and Mehedi Ahmed Ansary. "Assessment of Liquefaction Potential Index for Approach Road of Padma Multipurpose Bridge.” Journal of Mechanical and Civil Engineering (2015). http://dx.doi.org/10.9790/1684-1226132138.

[20] Shpresa Gashi and Neritan Shkodrani. "Seismic Soil Liquefaction for Deterministic and Probabilistic Approach Based on in Situ Test (CPTU) Data.” World Journal of Engineering and Technology (2015): 41-49. http://dx.doi.org/10.4236/wjet.2015.32004.

[21] Sanjay K. Jha and Kiichi Suzuki. "Reliability Analysis of Soil Liquefaction based on Standard Penetration Test." Computers and Geotechnics 36 (2009): 589-596. http://dx.doi.org/10.1016/j.compgeo.2008.10.004.

[22] A. Johari and A.R. Khodaparast. "Modelling of Probability Liquefaction Based on Standard Penetration Tests using the Jointly Distributed Random Variables Method.” Engineering Geology 158 (2013):1-14. http://dx.doi.org/10.1016/j.enggeo.2013.02.007.

[23] C. Hsein Juang and Chih-Chieh Lu. "Assessing Probability of Surface Manifestation of Liquefaction at a Given Site in a Given Exposure Time Using CPTU.” Engineering Geology 104 (2009): 223-231. http://dx.doi.org/10.1016/j.enggeo.2008.10.011.

[24] Rais Ahmad Khan and Mohammad Yousuf Shah. "Earthquake Induced Liquefaction Features in the Karewas of Kashmir Valley North-West Himalayas, India: Implication to Paleoseismicity.” Soil Dynamics and Earthquake Engineering 90 (2016): 101-111. http://dx.doi.org/10.1016/j.soildyn.2016.08.007.

[25] Ronaldo Luna and J.David Frose. "Spatial Liquefaction Analysis System.” Journal of Computingin Civil Engineering (January 1998): 48-56. https://doi.org/10.1061/(ASCE)0887-3801(1998)12:1(48). 